\title{
URGENSI REVITALISASI KEARIFAN LOKAL DI TENGAH ANCAMAN BENCANA ALAM DI INDONESIA
}

\author{
Pahrüdin HM \\ Peneliti dan Survejyòr Sosial CV. Bhumi Persada Swamitra, Sidoarjo Jawa Timur \\ roedy78@yahoo.co.id. Web blog: http://roedijambi.wordpress.com.
}

\section{Abstract}

In experiencing life, human being cannot be escaped from nature, especially the natural resources. In order to that, our ancestors have given us immeasurable local knowledges, like the forest restrictions; the depth restrictions; and many more, related to the relation of human being experiencedly with nature. Those indigenous knowledges intended by our ancestors to keeping continuity, preservation and concervation of natural resources that very necessary for human being and life. This article discusses about the importance of the Indonesian communities' local knowledges to keeping concervation and preservation of natural resources, like forest; water; river; and farm. Revitalize of local knowledges are significantly in threat of natural disasters at many Indonesian territories, from Aceh in west to Papua in east. In modern living of human, local knowledges still can be use with refer to it benefits and effects for human life and concervation of natural resources.

Key word: revitalize, natural disaster, local knowledge, natural resources,

\section{PENDAHULUAN}

Kepulauan Nusantara sejak'dahulu telah dikenal sebagai wilayah yang memiliki beragam sumber daya alam (natural resources), baik berupa bahan tambang seperti emas; perak; batubara; dan tembaga; maupun berupa hutan yang lebat dan perkebunan yang luas, terutama karet, kelapa sawit dan kakao. Di samping kedua jenis sumber daya tersebut, Indonesia juga dikenal sebagai kawasan yang memiliki laut yang luas dan sungai-sungai yang beraneka ragamnya. Pendek kata, Indonesia adalah negara yang kaya akan sumber daya alam yang melimpah sehingga mengemuka suatu ungkapan "tongkat kayu dan batu jadi tanaman" yang mengisyaratkan akan kesuburan negeri ini.

Namun demikian, belakangan ini Indonesia seakan sangat akrab dengan bencana alam yang ditimbulkan oleh beragam kekayaan sumber daya alam yang dimilikinya. Berdasarkan hasil interview Kompas (23 Februari 2010) dengan Koordinator Pusat Data Badan Nasional Penanggulangan Bencana (BNPB), Ridwan Yunus, jenis bencana yang melanda wilayah Indonesia didominasi banjiryang mencapai $35 \%$ dari total 6.632 kali bencana, disusul kekeringan $(18 \%)$, tanah longsor, angin topan dan kebakaran, masing-masing $11 \%$, sedangkan bencana banjir yang disusul tanah longsor tercatat sebanyak $3 \%$. Sementara itu, Badan Nasional Penanggulangan Bencana (BNPB) dalam sebuah laporannya merilis jumlah bencana alam yang terjadi di Indonesia sepanjang tahun 2011 mencapai angka 1.598 (www.okezonenews. com. 30 Desember 2011). Masih berdasarkan data BNPB, bencana alam hidrometeorologi seperti banjir, tanah longsor, kekeringan, dan angin puting beliung merupakan jenis bencana alam yang paling banyak (89\%) melanda Indonesia dalam sepuluh tahun terakhir (20022011). 
Bencana alam hidrometeorologi seperti tanah longsor terjadi di mana-mana, mulai dari Aceh di ujung barat hingga Papua di bagian timur Indonensia. Begitu juga dengan banjir. bandang yang seakan menjadi 'santapan' sehari-hari masyarakat Indonesia, bahkan di tempatitempat yang dulu dikenal memiliki sumber daya hutan yang luas sehingga tidak memungkinkan terjadinya banjir yang menelan korban jiwa seperti yang terjadi di Wasior Papua dan Aceh tahun 2011 yang lalu. Sumber daya air juga tidak luput dari bencana karena banyak laut, sungai dan mata air yang sudah tercemar, baik oleh limbah pertambangan maupun oleh beragam aktivitas manusia lainnya (Pahrudin HM, 2010: 143-159). Satu hal yang juga layak dicermati adalah mengemukanya 'serangan' ulat bulu di tahun 2011 lalu yang memakan daun-daun pohon di Jawa Timur, kemudian menyebar ke Jawa Tengah, Yogyakarta, Jawa Barat dan Jakarta serta sampai ke Sumatera Utara. Di samping menggunduli pohon-pohion yang ada di wilayah-wilayah tersebut, serangan ulat bulu ini juga mengancam manusia karena sudah memasuki rumah dan menimbulkan gatal-gatal di kulit. Belakangan ini kita juga dikejutkan dengan adanya binatang sejenis serangga (tomcat) yang 'menyerang' manusia, khusứsnya anak-anak, di Surabaya dan kemudian menyebar setidaknya di delapan wilayah di Jawa Timur. Meskipun tidak sampai merenggut korban jiwa, namun 'serangan' tomcat membuat tubuh manusia dihinggapinya gatal-gatal dan melepuh seperti terbakar akibat cairan yang dikeluarkannya.

Inilah sekilas realitas yang terjadi dengan masyarakat Indonesia yang mendiami negeri yang dikenal sebagai kawasan yang kaya akan beragam sumber daya alam dan seharusnya menikmati dampak-dampak positifnya. Di tengah kekhawatiran akan bencana yang bertubitubi tersebut, sebenarnya ada banyak cara yang dapat dilakukan. Salah satu upaya yang dapat dilakukan adalah membangun kesadaran untuk menggiatkan kembali (revitalisasi) implementasi beragam kearifan lokal yang berkaitan dengan sumber daya alam yang ada dalam masyarakat Indonesia.

Tulisan berikut akan mencoba menghadirkan paparan mengenai kearifan lokal Nusantara dan urgensi merevitalisasinya dalam kehidupan masyarakat kita. Hal ini perlu dilakukan karena para nenek moyang kita sebenarnya telah mewariskan beragam pengetahuan yang berkaitan dengan hubungan manusia dengan alam sehingga bencana-bencana tersebut di atas dapat dihindari atau paling tidak diminimalisasi kuantitas dan kualitasnya.

\section{MEMAHAMI KEARIFAN LOKAL}

Para pakar sosiologi, dan juga antropologi, menyakini bahwa dalam menjalani kehidupannya sehari-hari, manusia tidak akan. pernah terlepas dari alam sekitarnya (Rachmad, 2008; Poerwanto, 2008). Meskipun demikian, tidak semua manusia menyadari urgensitas hubungannya dengan alam yang harus selalu dijaga dan dipelihara dalam sebuah keseimbangan yang memungkinkannya terus berlangsung (sustainable). Kelompok manusia yang tidak menyadari pentingnya eksistensi alam dalam kehidupan manusia akan melakukan segala cara sesuai dengan keinginannya sehingga tidak jarang berimplikasi pada terjadinya beragam ketidakseimbangan bahkan juga bencana. Sementara sebaliknya, manusia yang sadar akan arti penting alam bagi kehidupannya akan memanfaatkannya sesual kebutuhan dan menciptakan beragam aturan atau metode agar keseimbangannya tetap selalu terjaga atau lestari. Inilah yang kemudian dikenal dalam khazanah ilmu pengetahuan modern dengan 'kearifan lokal'.

Secara sederhana, kearifan lokal (indigenous knowledge atau local knowledge) dapat dipahami sebagai pengetahuan kebudayaan yang dimiliki oleh masyarakat tertentu yang mencakup di dalamnya sejumlah pengetahuan kebudayaan yang berkaitan dengan modelmodel pemanfaatan dan pengelolaan sumber daya alam secara lestari (Zakaria, 1994: 56). Sebagaimana disebutkan sebelumnya bahwa dalam sejarah manusia terdapat orang-orang 
yang sadar dan peduli akan kelestarian alam-dan dari kelompok orang seperti inilah kearifan lokal tersebut berasal. Orang-orang yang memiliki kepedulian alam ini kemudian menciptakan aturan-aturan sederhana yang pada awalnya didapatkan melalui proses trial \& error dengan cara meneruskan aktivitas yang diyakini dapat melestarikan alam dan meninggalkan praktekpraktek yang berujung pada kerusakan (Mitchell, 2003: 299). Aturan atau ketentuan dalam format 'kearifan lokal' tersebut diciptakan oleh masyarakat dalam terminologi pantangan yang bercorak religius-magis dan aturan adat (Lubis, 2005: 251). Masyarakat dilarang untuk mendekat dan memasuki apalagi memanfaatkan tempat-tempat atau zona-zona yang ditetapkan sebagai 'larangan'. Agar ketentuan ini menjadi efektif, maka diciptakanlah beragam mitos atau cerita takhayul (superstition) sehingga orang-orang yang bermaksud untuk melakukan aktivitas destruktif menjadi takut. Cerita-cerita tersebut dibuat dalam beragam format, seperti adanya hantu yang menjadi penunggu zona tersebut, atau dapat pula berupa binatang buas yang akan memangsa siapapun yang melakukan aktivitas merusak di kawasan tersebut serta ada juga berupa penyakit aneh yang akan menyerang orang-orang yang bertindak tidak baik di dalamnya.

\section{MEREVITALISASI KEARIFAN LOKAL DALAM KEHIDUPAN MASYARAKAT}

Sebagaimana disebutkan sebelumnya bahwa ketentuan kearifan lokal (local knowledge) memang diciptakan dalam format religius-magis yang jika dipandang dengan 'kacamata' kemodernan saat ini akan kelihatan aneh dan tidak logis. Namun demikian, jika memperhatikan maksud dan tujuan dibalik mengemukanya beragam kearifan lokal yang ada dalam masyarakat kita maka tentu segala 'keanehan' dan ketidaklogisan tersebut akan berubah menjadi kekaguman. Mengemukanya beragam kearifan lokal dalam beragam format yang ada dalam masyarakat Indonesia sesungguhnya bukan hendak menakut-nakuti orang atau agar seseorang 'menyembah' sesuatu yang berada diluar kepercayaan agama yang dianutnya, seperti menyekutukan Allah dalam terminologi Islam. Akan tetapi bertujuan untuk menjaga keseimbangan dan kelestarian sumber daya alam yang ada dalam suatu masyarakat. Kearifan lokal yang ada dan dapat dijumpai di Indonesia mengemuka dalam beragam format sesuai dengan sumber daya alam yang ada dan dimiliki oleh masyarakatnya. Masyarakat yang memiliki sumber daya hutan memiliki apa yang dikenal dengan 'hutan larangan', dan masyarakat yang memiliki sumber daya air atau sungai mempunyai kearifan lokal yang biasa dikenal dengan 'lubuk larangan'. Sedangkan masyarakat yang bermatapencaharian utama sebagai nelayan di laut memiliki 'pantangan' untuk tidak terlalu banyak mengambil ikan di tengah laut dan menjaga terumbu karang, adapun masyarakat petani mengenal sistem 'tumpangsari' serta membiarkan laba-laba, kumbang dan burung berada di lingkungan pertanian mereka. Adapun masyarakat petani sawah mengenal kearifan lokal berupa pemeliharaan suatu ikan jenis tertentu dan membiarkan ular air berkembang biak di areal persawahan.

Di tengah 'serbuan' bencana alam yang seakan datang silih berganti menerjang negeri ini, ada baiknya kita kembali menengok beragam warisan yang ditinggalkan oleh nenek moyang kita. Kearifan lokal yang diwariskan para pendahulu kita tersebut memang bercorak religiusmagis yang tidak jarang menakutkan, namun dalam konteks sekarang tidak lagi dipandang demikian karena sebenarnya mengajarkan manusia pada kerendahan hati dan kebutuhan untuk belajar dari suatu komunitas sebelum kita mengajari mereka (Chamber \& Richard, 1995: xiii-xiv) . Nenek moyang kita telah mewariskan beragam format kearifan lokal yang bertujuan untuk menjaga kelestarian dan menyelamatkan lingkungan dan sumber daya alam sehingga dapat selalu dinikmati oleh generasi-generasi berikutnya.

Beragam analisis mengungkapkan bahwa terjadinya tanah longsor yang dan banjir bandang yang mencapai $11 \%$ dari total 6.632 bencana alam di tahun 2010 dan mayoritas (89\%) dari total 1.598 bencana alam di tahun 2011 di berbagai daerah di Tanah Air disebabkan 
oleh kian menyusutnya kualitas dan kuantitas hutan. Pohon-pohon yang berfungsi sebagai penyangga dan penyerap air tidak lagi banyak dan efektif seperti dulu akibat penebangan liar untuk beragam keperluan manusia. Akibatnya tentu dapat ditebak, terjadilah tanah longsor dan banjir bandang. Di sinilah letak urgensi kearifan lokal dalam konteks sumber daya hutan, yaitu adanya 'hutan larangan'. Ketentuan ini mengatur suatu kawasan hutan yang tidak boleh dimanfaatkan oleh masyarakat, apalagi ditebangi untuk keperluan apapun. Penentuan 'hutan larangan' biasanya ditetapkan berdasarkan pada efektivitasnya dalam menjaga kelestarian lingkungan, seperti di perbukitan, di sepanjang aliran sungai dan dekat dengan sumber mata air warga (Lubis, 2005: 251). Fungsinya sangat jelas agar bukit-bukit yang biasanya mengalami pengikisan oleh air hujan yang berakibat longsoran menjadi terhindari, begitu juga dengan banjir bandang yang dapat terhindari karena banyaknya pohon sehingga air hujan tidak sepenuhnya ditampung oleh sungai dan sebagai resapan air bagi sumber mata air yang biasa dimanfaatkan masyarakat.

Begitu juga dengan kian banyaknya kasus pencemaran sungai dan air akibat beragam keperluan manusia, seperti pertambangan dan lain sebagainya. Kearifan lokal yang dapat ditemukan dalam konteks ini mengemuka dalam format 'lubuk larangan', yaitu berupa penetapan zona-zona tertentu di sungai yang tidak boleh didekati dan dimanfaatkan oleh masyarakat. Di beberapa daerah di Sumatera, 'lubuk larangan' diberlakukan terhadap bagian sungai yang terdalam (lubuk) dan memiliki kontur air yang berputar-putar serta berada di suatu tikungan sungai (Pahrudin HM, 2010: 143-159). Jika mencermati kearifan lokal dalam bingkai 'lubuk larangan', maka akan didapatkan beberapa aspek yang sangat berguna bagi kelestarian lingkungan atau ekosisten sungai dan air. Revitalisasi 'Jubuk larangan' dalam kehidupan masyarakat akan mencakup paling tidak tiga aspek penting dalam kehidupan masyarakat, yaitu ekologis; ekonomis; dan sosio-kultural sekaligus. Menumbuhkembangkan kearifan lokal berupa 'lubuk larangan' di tengah masyarakat akan membuat lingkungan atau ekologi menjadi terjaga dan kalau pun sempat menghadapi ancaman degradasi tentu akan dapat dicegah sedini mungkin. Karena penerapan 'lubuk larangan' yang efektif, aktivitas pemanfaatan sungai dan air yang dilakukan masyarakat akan terkontrol dan kegiatan-kegiatan destruktif seperti penambangan yang akan berujung pada degradasi lingkungan dapat dihindari. Sedangkan secara ekonomis, efektivitas penerapan 'lubuk larangan' akan berimplikasi positif bagi kehidupan masyarakat karena beragam resources yang terdapat dalam zona 'pantangan' tersebut, seperti ikan yang memang banyak terdapat di tempat-tempat yang sesuai dengan ketentuan 'lubuk larangan', dapat dimanfaatkan sesuai dengan ketentuan yang ditetapkan. Hal ini karena 'pantangan' yang ada pada 'lubuk larangan' tidak sepenuhnya diberlakukan sepanjang waktu dan sepanjang tahun. Ada waktu-waktu tertentu, biasanya saat lebaran, yang memperbolehkan warga masyarakat untuk bersama-sama memanfaatkan beragam resources yang ada dalam 'lubuk larangan' tersebut. Seluruh anggota masyarakat bersamasama mengambil ikan-ikan yang ada dalam 'lubuk larangan' tersebut untuk dikonsumsi oleh keluarga, sedangkan sebagaian besar ikan lainnya dijual oleh desa dan hasil penjualannya digunakan untuk beragam keperluan publik, seperti membantu pembangunan tempat ibadah, sarana kesehatan dan lain sebagainya. Adapun dari aspek sosio-kultural adalah kebersamaan dan kesamarataan beragam lapisan sosial dalam memanfaatkan hasil 'lubuk larangan' tanpa memandang status sosial mereka. Di samping itu, ajang 'pembukaan' kearifan lokal ini juga dimanfaatkan sebagai pariwisata budaya karena biasanya juga mengetengahkan beragam atraksi budaya masyarakat setempat, khususnya yang berkaitan dengan budaya sungai. Demikianlah sebuah kearifan lokal yang seringkali dianggap sebagai ketinggalan zaman ternyata dapat mengait pada paling tidak tiga aspek penting dąlam kehidupan masyarakat.

Masyarakat nelayan juga mengenal kearifan lokal, di antaranya berupa 'pantangan' untuk tidak terlalu banyak menangkap ikan di tengah-tengah laut (Mitchell, 2003: 320). Aturan 
ini sudah lama mengakar dalam masyarakat nelayan, bahkan juga di banyak komunitas nelayan di seluruh dunia, karena dengan mengambil ikan dalam jumlah yạng terlalu banyak di tengahtengah laut, maka kuantitas dan kualitas ikan yang akan berkumpul di tepi laut menjadi sedikit atau bahkan tidak ada sama sekali. Dengan minimnya keberadaan ikan di tepi laut, atau laut dangkal, maka nelayan-nelayan yang kebetulan tidak memiliki peralatan tangkap yang lengkap tentu tidak akań kebagian anugerah yang diberikan Tuhan dari laut. Di samping itu, melalui kajian ilmu pengetahuan perikanan dan kelautan modern dapat diketahui bahwa beberapa jenis ikan justru bertelur dan berkembangbiak di tepi laut, atau laut dangkal. Dengan menangkap ikan dalam kuantitas yang besar di tengah-tengah laut di samping akan mematikan kesempatan kelompok nelayan kecil untuk mencari rezeki, juga akan mengganggu keberlanjutan spesiesspesies ikan tersebut di kemudian hari. Kearifan lokal lainnya yang dapat ditemukan dalam komunitas nelayan adalah pelestarian yang mereka lakukan terhadap terumbu karang di laut dan hutan bakau (mangrove) di tepi pantai. Kedua benda ini sangat berarti bagi kelangsungan hidup para nelayan karena terumbu karang dan pohon bakaulah yang menjadi tempat perkembangbiakan beragam spesies ikan. Dengan melakukan perlindungan dan pelestarian terhadap terumbu karang dan bakau, maka kelangsungan hidup beragam spesies ikan akan terus terjaga yang berarti kelangsungan hidup nelayan dan anggota keluarganya juga dapat terus berlanjut.

Kelompok masyarakat lainnya yang di dalamnya dapat ditemukan kearifan lokal yang sudah sangat mengakar adalah masyarakat petani. Kelompok terbesar dalam komposisi penduduk Indoensia ini mengenal sistem 'tumpangsari' serta membiarkan laba-laba, kumbang dan burung berada di lingkungan pertanian mereka serta pemeliharaan suatu ikan jenis tertentu dan membiarkan ular air berkembang biak di areal persawahan (Mitchell, 2003: 300). Sistem 'tumpangsari' adalah praktek penanaman beragam biji-bijian sebagai bagian dari peladangan berpindah yang banyak meniru kompleksitas dan keragaman sistem vegetasi wilayah subtropis dan tropis. Model pertanian ini dilakukan dengan cara menanam beberapa jenis tanaman yang berbeda dalam suatu areal atau petak tanah secara bersamaan. Pada awalnya, sistem pertanian ini dianggap ketinggalan zaman dan tidak sesuai dengan ilmu pertanian modern karena tidak efisien secara kuantitas dan kualitas hasil yang akan didapatkan. Akan tetapi terdapat tujuan yang baik dan penting adanya kearifan lokal ini, yaitu untuk melindungi tanah dari sinar matahari langsung, mengurangi pemanasan langsung pada permukaan tanah, menjaga permukaan tanah dari proses erosi, penggunaan volume tanah secara efisien dan mengurangi kerentananan tanah dari hama dan serangga perusak. Hal ini dapat terjadi karena perbedaan kecepatan tumbuh beragam tanaman tersebut membuat tanah menjadi permanen, di samping itu juga karena tanahnya selalu ditutupi oleh tanaman tersebut secara terus menerus serta sistem akar tanaman tersebut yang bervariasi.

Hama menjadi momok yang menakutkan bagi para petani karena akan berakibat pada penurunan produktivitas pertanian, bahkan dapat pula gagal sama sekali. Pada tahun 1974, ribuan hektar tanaman padi yang ada di Pulau Jawa dan Bali diserang dan dirusak oleh hama wereng serta memusnahkan 3 juta ton produksi padi (Rigg, 1999: 62-63). Untuk mengatasi hal ini, sistem pengetahuan modern menciptakan beragam varitas padi baru yang diyakini kebal terhadap serbuan hama bernama Latin nilaparvata lugens yang selama ini menyerang padipadi jenis lokal. Namun demikian, varitas-varitas padi baru ini ternyata tetap diserang wereng yang telah bertransformasi menjadi hama yang berjenis baru juga. Padahal dalam masyarakat petani sebenarnya mengenal suatu kearifan lokal yang selama ini dipakai untuk menangkal hama wereng, yaitu membiarkan suátu jenis kumbang dan laba-laba berkembangbiak di areal pertanian. Kedua spesies hewan yang biasa beraktivitas di daun-daun padi ini menjadikan wereng sebagai salah satu makanannya sehingga secara alami dapat mengontrol populasi 
wereng yang sering ditakutkan para petani tersebut. Seekor laba-laba, seperti laba-laba serigala (Lyosa pseudoannulata), dapat memangsa 5-15 hama wereng setiap harinya (Rigg, 1999) dan bagaimana jika ada ratusan laba-laba di sawah yang tentunya akan dapat mengurangi hawa ereng secara signifikan.

Di samping wereng, hama ulat juga menjadi sesuatu yang dihindari oleh petani dan masyarakat pada umumnya sebagaimana yang kini banyak terjadi di berbagai daerah di Jawa dan Sumatera. Untuk mengatasi hal ini sebenarnya juga ada pengetahuan lokal yang kini seakan ditinggalkan, yaitu pelestarian beragam jenis burung yang memangsa ulat-ulat tersebut. Namun demikian, seiring dengan kian menipisnya areal hutan yang menjadi habitatnya akibat beragam keperluan manusia, populasi burung pun menjadi berkurang secara drastis sehingga ulat-ulat bulu menjadi semakin merajalela akibat ketiadaan pemangsa alaminya. Ular air dan ikan-ikan kecil juga dibiarkan dan pelihara oleh para petani sawah sebagai pengetahuan lokal yang mereka miliki untuk menghindarkan pertanian mereka dari beragam hama yang terdapat di akar-akar padi mereka. Serbuan ulat bulu di tahun 2011 dan serangga tomcat di beberapa daerah di Jawa Timur di awal 2012 ini bisa jadi merupakan dampak dari penggunaan insektisida yang berlebihan di lahan-lahan pertanian dan perkebunan. Penggunaan obatobatan kimia memang membuat tanaman tumbuh dengan baik dan lebih cepat, tetapi di sisi lain membuat pemangsa alami hama tanaman dan beragam jenis serangga, seperti laba-laba, burung dan kumbang, juga ikut mati. Akibatnya ulat bulu dan serangga dengan leluasa hidup dan berkembangbiak serta berkeliaran bahkan sampai ke pemukiman masyarakat.

Demikianlah beragam pengetahuan lokal yang dimiliki oleh masyarakat kita, beberapa di antaranya masih tetap dipertahankan dan beberapa di antara yang lainnya sudah dilupakan dan ditinggalkan. Dunia modern yang ditandai dengan penggunaan sepenuhnya nalar ilmiah dalam setiap aktivitas manusia memang sedikit banyak telah menenggelamkan warisanwarisan masa lalu yang ditinggalkan nenek moyang. Nalar ilmiahị menjadi satu-satunya indikator penerimaan suatu hal yang dapat dilakukan oleh komunitas masyarakat, jika dianggap tidak logis maka cenderung akan ditinggalkan. Itulah konsekuensi yang harus dialami oleh beragam warisan masa lampau dalam dunia modern. Terdapat banyak dampak yang ditimbulkan oleh modernisasi, baik positif maupun yang dianggap negatif. Efek positif yang dihasilkan oleh modernisasi di antaranya adalah perkembangan peralatan komunikasi dan informasi yang membuat dunia layaknya sebuah perkampungan dalam bingkai 'globalisasi' atau desa buana sehingga memungkinkan manusia berinteraksi dengan banyak orang di belahan bumi lainnya. Sedangkan efek negatifnya terjadinya pergeseran nilai dan kepercayaan di tengah-tengah masyarakat dan lain sebagainya (Giddens, 2005; Piliang, 2004a; Piliang, 2004b).

Beragam local knowledge sebagaimana yang dikemukakan di atas memang sangat bernuansa religius-mistis dan cenderung tidak masuk akal dalam nalar modern saat ini. Namun demikian, warisan-warisan nenek moyang kita tersebut sebenarnya memiliki aspek positif yang sangat besar bagi kelangsungan dan kelestarian beragam sumber daya yang sangat berguna di sekeliling kita. Hutan Larangan, Lubuk Larangan, pelestarian burung dan ular yang keberadaannya dilengkapi dengan bumbu-bumbu mistik yang berkonotasi menakutkan jika dilihat sepintas lalu adalah kegiatan-kegiatan yang ketinggalan zaman. Namun lihatlah manfaat positifnya bagi pelestarian hutan, sumber air dan sungai serta pertanian yang sekian lama terbukti mampu mencegah aktivitas yang berujung pada degradasi sumber daya alam dan lingkungan sedini mungkin. Bumbu-bumbu mistis yang dianggap tidak logis dalam beragam kearifan lokal tersebut sebenarnya dimaksudkan untuk mencegah masyarakat dalam melakukan perbuatan yang 'semena-mena' terhadap sumber daya alam tersebut. Karena tingkat pengetahuan masyarakat pada saat itu masih pada taraf teologi, maka aturan dan ketentuan pelestarian sumber daya alam yang dibuat pun harus mengikuti karakteristik seperti 
itu. Karena model berpikir manusia pada masa diciptakannya kearifan lokal ini masih belum menggunakan penalaran ilmiah, maka bumbu mistik berupa makhluk gaib dan kekuatan supernatural lainnya menghiasi aturan dan ketentuan tersebut. Hal ini jika meminjam istilah yang dikemukakan oleh Auguste Comte (1798-1857), seorang ilmuan sosial terkemuka asal Perancis yang dianggap sebagai penemu fisika sosial yang pada tahun 1839 diganti menjadi sosiologi. Menurut Comte, perkembangan pemikiran manusia terbagi atau melalui tiga tahapan (fase), yaitu: teologi atau fiktif; metafisik atau abstrak; dan ilmiah atau positif. Pada fase teologi, pemikiran manusia menganggap bahwa semua gejala dihasilkan oleh tindakan langsung dari hal-hal yang supernatural dan berlangsung pada era sebelum 1300. Sedangkan fase kedua (metafisik) berlangsung pada era 1300-1800 yang ditandai dengan pemikiran manusia yang menganggap bahwa semua gejala bukan berasal dari hal-hal yang supernatural seperti pada tahapan pertama, tetapi berasal dari kekuatan-kekuatan abstrak. Terakhir, fase ilmiah yang berlangsung sejak era 1800 yang ditandai dengan model pemikiran manusia yang berlandaskan pada penalaran dan pengamatan yang kelak memunculkan pengetahuan ilmiah (Ritzer \& Goodman, 2004: 16-20; Johnson, 1988: 84-86; Jary, 1991: 107-109; Abercrombie, 2006: 104). Dengan demikian, di dunia modern atau fase ilmiah menurut Comte yang ditandai dengan penggunaan nalar ilmiah sebagai indikator penerimaan sebuah aktivitas, kearifankearifan lokal tersebut tetap dapat diterapkan dengan memperhatikan manfaat-manfaat positif yang ditimbulkannya.

\section{PENUTUP}

Beragam bencana alam yang 'rutin' menimpa negeri yang dikenal memiliki sumber daya alam yang kaya ini seharusnya menyadarkan kita akan signifikansi kelestarian alam. Nenek moyang kita telah mewariskan beragam kearifan lokal yang sebenarnya dimaksudkan untuk menjaga kelestarian dan kesinambungan alam dengan beragam sumber daya di dalamnya. Meskipun dunia modern meniscayakan penggunaan nalar ilmiah dalam beraktivitas, tetapi beragam kearifan lokal tersebut sebenarnya bertujuan sangat baik dan mulia meskipun dibumbui oleh hal-hal yang mistik. Merevitalisasi beragam kearifan lokal yang ada dalam masyarakat Indonesia sudah semestinya gencar dilakukan agar aneka ragam bencana alam dapat diantisipasi atau paling tidak diminimalisasi.

Upaya yang dilakukan untuk pelestarian alam dalam bingkai revitalisasi kearifan lokal sehingga beragam bencana alam paling tidak dapat dikurangi tentu tidak cukup hanya dilakukan oleh sekelompok orang saja. Saat ini yang sangat diperlukan adalah kesadaran kolektif segenap komponen masyarakat untuk melestarikan alam melalui revitalisasi kearifan lokal yang dimiliki oleh masing-masing komunitas. Selanjutnya, agar upaya ini dapat berjalan efektif perlu adanya payung hukum, paling tidak berupa peraturan daerah yang mengatur keberadaan kearifan lokal tersebut. Hal ini sebagaimana yang dilakukan di Kabupaten Tapanuli Selatan yang mengeluarkan Peratuan Daerah No. 19/1988 tentang Pengelolaan Lubuk Larangan. Hal yang sama juga dapat dilakukan pada beberapa kearifan lokal masyarakat Indonesia lainnya, seperti Hutan Larangan. Upaya ini sangat mungkin dilakukan seiring dengan berlakunya UndangUndang Otonomi Daerah No. 22/1999 yang memberi peluang bagi pemerintah daerah untuk menata wilayahnya dengan memperhatikan karakteristik budaya dan tradisinya yang khas.

\section{DAFTAR PUSTAKA}

Abercrombie, Nicholas et.al. (2006) Kamus Sosiologi. Yogyakarta: Pustaka Pelajar.

Caplow, Theodore (1971) Elementary Sociology. NJ: Prentice-Hall \& Englewood Cliffs. 
UNISIA, Vol. XXXIII No. 75 Juli 2011

Chamber, Robert. \& P. Richards (1995) 'Preface', dalam D.M. Warren dkk. (peny.). The Cultural Dimension of Development: Indigenous Systems. London: Intermediate Technology Publications.

Giddens, Anthony (2005) Konsekuensi-Konsekuensi Modernitas. Yogyakarta: Pustaka Pelajar.

Horton, Paul B. \& Chester L. Hunt (1984) Sosiologi. Surabaya: Penerbit Erlangga. Jilid I.

Johnson, Doyle Paul (1988) Teori Sosiologi Klasik dan Modern. Jakarta: PT. Gramedia Pustaka Utama.

Jary, David. \& Julia Jary (1991) Collins Dictionary of Sociology. Glasgow: HarperCollins Publishers.

Lubis, Zulkifli B. (2005) "Menumbuhkan (Kembali) Kearifan Lokal Dalam Pengelolaan Sumber Daya Alam di Tapanuli Selatan". Jurnal Antropologi Indonesia. Volume 29 No. 3 (2005) Departemen Antropologi Fisipol Universitas Indonesia Jakarta.

Mitchell, Bruce et.al. (2003) Pengelolaan Sumber daya dan Lingkungan. Yogyakarta: Gadjah Mada University Press.

Pahrudin HM. (2010) "Menelisik Aktivitas Penambangan Emas di Sungai Tabir-Jambi" dalam Jurnal Sosiologi Reflektif Vol. 4 No. 2 April 2010. Program Studi Sosiologi UIN Sunan Kalijaga Yogyakarta.

Piliang, YasrafAmir (2004a) Dunia Yang Dilipat, Tamasya MelampauiBatas-Batas Kebudayaan. Yogyakarta: Jalasutra.

Yogyakarta: Jalasutra.

Poerwanto, Hari (2008) Kebudayaan dan Lingkungan Dalam PerspektifAntropologi. Yogyakarta: Pustaka Pelajar.

Rigg, J. (1999) "Local Knowledge, Expert Knowledge". dalam J. Rigg (Ed.) The Human Environment. Jakarta: Archipelago Press.

Ritzer, George. \& Douglas J. Goodman (2004) Teori Sosiologi Modern. Jakarta: Kencana.

Zakaria, Y.R. (1994) Hutan dan Kesejahteraan Masyarakat. Jakarta: Penerbit Walhi.

www.okezonenews.com//bnpb-bencana-alam-terjadi-ditahun-2011 (akses 20 Maret 2012)

www.kompas.com//statistik-bencana-alam (akses 20 Maret 2012)

www.waspadaonline.com//daftar-bencana-banjir-di-Indonesia (akses 20 Maret 2012)

Penulis menempuh pendidikan sarjana di Fakultas Adab UIN Sunan Kalijaga Yogyakarta dan pascasarjana di Progran Pascasarjana Sosiologi Universilas Gadjah Mada Yogyakarla. Pernah bekerja sebagai Seknetaris Rekior Universitas Proklamasi 45 Yogyakarta (20092010) dan Ahli Sosiologi pada PT. Gama Konsulindo Malang timtuk proyek Rencana Pembangunan Jangka Panjang (RPJP) Kota Sirrabaya Tahun 2010-2025. Saat ini bekerja sebagai Peneliti dan Surveyor Sosial di CV. Bhumi Persada Swamilra Sidoarjo Jawa Timur:

Tinggal di Jalan Wulth 8F Papringan Yogyakarta 55281. Nomor Handphone: 085228672292 (As) \& 087839885015 (XI). Alamal e-mail: roedy78@yahoo,coid. Web blog: httpil/roediiambi.wordpress.coin. 